\title{
China's chances, China's choices in global tobacco control
}

\section{Ruth E Malone}

Long viewed by tobacco companies as a 'prize' market because of its huge population, ${ }^{1}$ China trails most other countries in implementing strong, effective tobacco control policies. Advertising still proliferates, workplaces are not widely smokefree, and cigarette taxes, while increased modestly, remain ineffectively designed for tobacco control purposes. Meanwhile, some one million Chinese people die yearly from tobacco-caused diseases. ${ }^{2}$

Yet with its giant state-owned tobacco industry and very limited competition, the Chinese government could relatively easily make China the global leader in public health rather than the global leader in profiting from its own people's disease and death. One way to do this would be to raise taxes at the consumer level to an amount significant enough to reduce consumption, as suggested by a paper in this issue of Tobacco Control, ${ }^{3}$ and to dedicate those taxes to programmes that change social norms about tobacco and help people to quit.

China's chances of doing so, however, depend on shifting the perspectives of those leaders who still view cigarette smoking as an accepted everyday practice, many of whom are most probably cigarette smokers themselves. In a country that permits China Tobacco Company to fund elementary schools, wherein banners are displayed reading "Tobacco can help you become an achiever," ${ }^{4}$ change will take sustained effort from within and international support from without. As with tobacco companies everywhere, the Chinese tobacco industry has worked hard to convey the idea that inhaling toxic gases from a paper tube some 20 times a day is normal. In a country that consumes more than $37 \%$ of the world's cigarettes, where almost $60 \%$ of men smoke, ${ }^{5}$ it is not surprising that tobacco use is ubiquitous and widely accepted. What is perhaps still surprising to many in the global tobacco control community is that China ratified the World Health Organization Framework Convention on Tobacco Control (FCTC), marking a commitment to implement

Correspondence to Professor Ruth E Malone, Department of Social and Behavioral Sciences, University of California, 3333 California Street, Suite 455, San Francisco, CA 94118, USA; ruth.malone@ucsf.edu stronger measures to stem the tobacco epidemic.

As with tobacco companies everywhere, the Chinese tobacco industry has also linked its deadly products with meaningful imagery to make it seem impossible that cigarettes could be regarded as other than normal, everyday consumer items. ${ }^{6}$ At the WHO FCTC Third Conference of the Parties (COP-3) in Durban in late 2008, I heard the Chinese delegation argue forcefully and passionately during discussion of guidelines for implementing Article 11 (which deals with packaging and labelling of tobacco products) that their country could not possibly institute graphic warnings on cigarette packs because those packs featured revered cultural icons. To cover them with graphic warnings, they explained, would convey a terrible disrespect. Perhaps the Chinese delegates really believed this. But I also heard the ripples of laughter that followed this assertion, recognition by the rest of the world's delegates that the exploitation of revered cultural images to sell death is itself disrespectful. The provision in question was not weakened.

Unfortunately, while China's costs of tobacco use in disease and death are estimated at \$US5 billion yearly and growing, ${ }^{7}$ profits and taxes from its tobacco corporation top 10 times that amount. ${ }^{8}$ However, the effects of tobacco are cumulative, and unless they are addressed, tobacco-related disease and death will begin to hurt China's booming economy in the coming years. Also, despite its profitability, cigarette production is of declining importance to the economy, contributing less than $1 \%$ to the total value of industrial production in $2002 .^{2}$

'Face' is an important notion in China, on both the level of individuals and that of the state. One does not want to act in a way that may result in 'losing face' - that is, one wants to act in the socially correct way. This means that tobacco control advocates must work to change norms around tobacco's meaning in society, as in the television campaign 'Giving cigarettes is giving harm', illustrated on this issue's cover. This campaign, which is helping to change the meaning of tobacco's symbolic associations in China with gift-giving and special occasions, shows the hapless giver of cigarettes losing face as the recipients shrink back in horror at the real consequences the 'gift' represents. The wonderful video is well worth a look (http:// www.worldlungfoundation.org/ht/d/sp/i/ 7217/pid/7217).

Perhaps the desire to not lose face at the level of the state accounted for the fact that the 2008 Olympics inspired stronger smokefree policies in Bejing: on display before the world, China sought to emphasise its commitment to health. In general, China is showing a new and encouraging openness to addressing global public health threats more aggressively, as seen in its response to the swine flu outbreaks last year. Tobacco control education is being provided for the first time in schools of public health. ${ }^{9}$ $\mathrm{Xu}$ Guihua, vice president of the China Tobacco Control Association, has asserted that China will indeed meet its FCTC obligation and ban tobacco advertising by 2011. ${ }^{10}$ These and many other current developments there are all signs of hope.

In the end, the choices China makes will determine, in important ways, its chances-its chances for a healthy population and workforce and its chances for saving face in the global public health community by leading the world in implementing the treaty it has ratified, rather than trying to weaken it.

\section{Contributors RM wrote the editorial.}

Competing interests Ruth Malone owns one share each of Philip Morris/Altria, Philip Morris International and Reynolds American tobacco company stock for research and advocacy purposes. She served as a tobacco industry documents consultant for the US Department of Justice in USA vs Philip Morris et al.

Provenance and peer review Commissioned; not externally peer reviewed.

Tobacco Control 2010;19:1-2.

doi:10.1136/tc.2009.035485

\section{REFERENCES}

1. O'Sullivan B, Chapman S. Eyes on the prize: transnational tobacco companies in China 1976-1997 Tob Control 2000;9:292-302.

2. Hu T-W, Mao Z, Ong M, et al. China at the crossroads: the economics of tobacco and health. Tob Control 2006;15 (suppl 1):i37-41

3. Hu TW, Mao Z, Shi J, et al. Recent tobacco tax rate adjustment and its potential impact on tobacco control in China. Tob Control 2010;19:58-64.

4. Loveland G. Company posts pro-tobacco messages in Sichuan school. Examiner, December 20 2009, http://www.examiner.com/x-15615-Asia-HeadlinesExaminer y2009m12d20-Company-postsprotobacco-messages-in-Sichuan-school laccessed 11 January 2010)

5. Shafey 0, Eriksen M, Ross $\mathrm{H}$, et al. The tobacco atlas 3rd ed. Atlanta: American Cancer Society, 2009

6. Malone RE. On tobacco industry cultural appropriation Tob Control 2009;18:425-6. 
7. Sung $\mathbf{H}-\mathbf{Y}$, Wang $\mathrm{L}$, Jin $\mathrm{S}$, et al. Economic burden of smoking in China, 2000. Tob Control 2006;15:15-11.

8. http://www.China Knowledge.com. China's tobacco industry net profit, tax hit RMB 388 bln 2009,

December 18. http://www.chinaknowledge.com/
Newswires/News_Detail.aspx?type $=1 \&$ NewsID $=$ 12759):(accessed 18 Dec 2009).

9. Yang T, Yang X, Lv O, et al. China's first historic efforts to develop a tobacco control advocacy workforce via schools of public health. Tob Control 2009;18:422-4.
10. Glogan T. China: still a Mecca for the tobacco industry. Tobacco Journal International 2008; http:// www.tobaccojournal.com/China_Still a Mecca for the tobacco industry.48796.0.html laccessed 18 Dec 2009). 